\title{
Genotype distribution of $T$ cell receptor $\beta$ gene in Indonesian nasopharyngeal carcinoma patients
}

\author{
Yurnadi, ${ }^{1,2}$ Purnomo Soeharso, ${ }^{1}$ Dwi A. Suryandari, ${ }^{1}$ Nukman Moeloek, ${ }^{1}$ R. Susworo ${ }^{3}$ \\ ${ }^{1}$ Department of Medical Biology, Faculty of Medicine Universitas Indonesia, Jakarta, Indonesia \\ 2 Program Doctoral Medical Biology Student, Faculty of Medicine Universitas Indonesia, Jakarta, Indonesia \\ ${ }^{3}$ Department of Radiotherapy, Faculty of Medicine Universitas Indonesia and Ciptomangunkusumo Hospital, Jakarta, Indonesia
}

\begin{abstract}
Abstrak
Latar belakang: Karsinoma nasofaring (KNF) merupakan penyakit genetik multifaktorial, bersifat endemik dan mempunyai perbedaan signifikan dalam distribusi geografis. Selain faktor virus Epstein Barr (EBV), insiden KNF juga dipengaruhi oleh faktor genetik seperti polimorfisme gen reseptor sel Tlokus $\beta$ (TCR- $\beta$ ). Penelitian ini bertujuan untuk mengetahui hubungan polimorfisme gen TCR- $\beta$ dengan suseptibilitas individu untuk berkembang menjadi KNF pada populasi Indonesia.
\end{abstract}

Metode: Penelitian dilakukan dengan teknik PCR-RFLP menggunakan enzim restriksi Bgl II pada gen TCR- $\beta$. Analisis PCR-RFLP gen TCR- $\beta$ digunakan untuk mendeterminasi alotip gen TCR- $\beta$ pada penderita KNF dan kontrol dan pada kelompok etnis Cina dan pribumi dalam populasi Indonesia.

Hasil: Hasil penelitian menunjukkan bahwa distribusi alotip gen TCR- $\beta$ pada penderita KNF dan kontrol tidak berbeda bermakna $(p>0,05)$. Frekuensi alel A meningkat pada penderita KNF. Distribusi alotip gen TCR- $\beta$ antara etnis Cina dan kelompok pribumi tidak memperlihatkan perbedaan bermakna $(p>0,05)$.

Kesimpulan: Distribusi alel gen TCR- $\beta$ antara kelompok KNF dengan kelompok kontrol tidak menunjukkan perbedaan. Distribusi alel gen TCR- $\beta$ antara etnis Cina dan pribumi tidak menunjukkan perbedaan. Polimorfisme gen TCR- $\beta$ tidak berhubungan dengan KNF dan etnis pada populasi Indonesia. (Med J Indones 2011; 20:171-7)

\begin{abstract}
Background: Nasopharyngeal carcinoma (NPC) is a multifactorial genetic disease, characteristically endemic and shows considerable differences in its geographical distribution. Besides infection with EBV, genetic factors such as polymorphisms of TCR- $\beta$ gene contribute to the incidence of NPC. This study investigates the association of TCR- $\beta$ gene polymorphisms with individual susceptibility to develop NPC in Indonesian ethnic groups.

Methods: The study was carried out by the PCR-RFLP method using Bgl II restriction enzyme to digest TCR- $\beta$ gene. The PCR-RFLP analysis of TCR- $\beta$ gene was used to determine allotypes of TCR- $\beta$ gene in NPC patients and control among ethnic Chinese and indigenous groups in the population of Indonesia.

Results: The results indicate that the distribution of TCR- $\beta$ gene allotypes between NPC patients and controls are not significantly different $(\mathrm{p}>0.05)$; however, the frequency of A allele tends to increase in NPC patients. The distribution of TCR- $\beta$ gene allotypes between Chinese ethnic group was not significantly different from indigenous groups $(p>0.05)$.

Conclusion: The distribution of TCR- $\beta$ gene allele between NPC group and control groups showed no difference. The distribution of TCR- $\beta$ gene between ethnic Chinese and indigenous groups showed no difference. Polymorphisms of TCR- $\beta$ gene are not associated with NPC and ethnic groups in Indonesian population. (Med J Indones 2011; 20:171-7)
\end{abstract}

Key words: $E B V$, NPC, polymorphism, susceptibility, TCR- $\beta$ gene

Nasopharyngeal carcinoma (NPC) is a genetic multifactor disease that has an endemic character. ${ }^{1} \mathrm{NPC}$ is a subset of squamous carcinoma cells at the head and neck. NPC is relatively rare in the world ( 80.000 new cases per year). Nevertheless, NPC shows considerable differences in geographic distribution. ${ }^{2}$ Although many cases are found in countries with non-Mongoloid residents, South China still occupies the highest incidence with 2.500 new cases per year. NPC incidence in Mongoloid ethnics is a dominant factor; the frequency is quite high in South China, Hong Kong, Vietnam, Thailand, Malaysia, Singapore, and Indonesia. ${ }^{3}$
Parkin et al. stated that the incidence of NPC by age average is generally less than $1 / 100.000$ except the population in South China and in other Chinese regions, South-East Asia, South West India, Greece, Algeria and Tunisia, and in Alaska and Greenland. ${ }^{4}$ Incidence of NPC is higher in men than in women with a ratio 2.3:1. In the population, the level of NPC risk is progressive along with rising of age. ${ }^{4}$ In Indonesia, NPC can be found in many areas although case numbers vary among the regions. In Jakarta, the prevalence of the disease is more than 100 cases per year. Bandung shows an average of 60 cases, while 
Makassar 25 cases, Palembang 25 cases, Denpasar 15 cases, and West Sumatera 11 cases. Considering also the numbers of cases in Medan, Semarang, Surabaya and other cities, it indicates that NPC has spread across the Indonesian region.

Dutt et $\mathrm{al}^{5}$ argued that the incidence of NPC is multifactorial and cannot be entirely explained. Current evidence supports existence of a relationship between environmental factors, food, genetics, and infection with Epstein - Barr virus (EBV). ${ }^{5}$ Besides ethnic factors, increased incidence of NPC is reported to have links with environmental and socioeconomic factors, habits such as cigarette smoking and consumption of fermented and conserved food (e.g., salted and fumigated fish) and vegetable oils containing nitrosamines, as well as exposure to soot, dust with formaldehydes. Each of these factors can activate EBV and promote growth of NPC. ${ }^{6,7}$ EBV infection is an important environmental factor in the aetiology of NPC tumorigenesis. EBV is not found in all normal cells of nasopharyngeal epithelium and the EBV genome is not present in all normal cells of nasopharyngeal epithelium, however, it can be found in all NPC cells. ${ }^{2}$

The cells of the immune system spontaneously recognize tumour cells and T- lymphocytes ( $\mathrm{T}$ cells) become main effector cells in the immune surveillance of cancer. $\mathrm{T}$ cells recognize antigens presented by the major histocompatibility complex (MHC) through distribution of $\mathrm{T}$ cell receptor (TCR) clones, until distribution clones TCR can detect and see specific band T cell base uniqueness TCR. ${ }^{8}$ Cytotoxic T cells are T-lymphocytes which mediate cytotoxic reactions to virus infected cells and stimulate macrophages to phagocyte these cells. ${ }^{9}$

Hence, T cells, which eliminate virus-infected cells, play an important role in pathogenesis of NPC. Restriction fragment length polymorphisms (RFLP) of germ-line of TCR genes from Singaporean Chinese patients with NPC and healthy controls were analysed by Southernblot technique and hybridization with radioactively labeled TCR cDNA probes. The results suggested that TCR restriction may be important in the pathogenesis of NPC. ${ }^{10} \mathrm{~T}$ cells generally shared arranged immune response through several $\mathrm{T}$ cell receptors. Thus, $\mathrm{T}$ cell receptors play a role in the immune system and several of abnormalities and diseases have been shown to occur along with $\mathrm{T}$ cell dysfunction. ${ }^{11}$

Possibilities to assess variant TCR at condition of T cell dysfunction can be detected by visible change at locus of TCR to assess abnormality of expression or TCR gene function. ${ }^{12}$ Polymorphism of the TCR gene can influence $\mathrm{T}$ cell function, especially in occurrence and pathogenesis of diseases, for example hepatitis B. Polymorphism of TCR gene presenting allele and genotype TCR is estimated to be a predisposing factor of NPC. Polymorphism of TCR- $\beta$ gene is related to individual susceptibilities to infection of hepatitis $B$ virus (HBV) and it was reported that polymorphic sites of TCR- $\beta$ gene exist at span of $\mathrm{C} \beta_{1}-\mathrm{C} \beta_{2}{ }^{13}$

The genetic factor is a primary factor in the pathogenesis of NPC and epidemiology data states the importance of genetic factor as the cause of this disease. Nevertheless as a whole molecular genetic aspects from NPC such as polymorphisms of TCR- $\beta$ gene have not yet been able to be evaluated. Conversely, nowadays no experiment has reported TCR- $\beta$ gene polymorphisms in Indonesian population and its relation with susceptibilities to NPC.

The aims of the study are to investigate distribution of genotype TCR- $\beta$ gene in Indonesian population and its relation with individual susceptibilities to NPC.

\section{METHODS}

\section{Subject}

The research was done from August 2006 till December 2008 and research subjects are patients who have been diagnosed of having NPC, whereas controls are healthy individuals. All research subjects were given informed consent before taking part in this research. Diagnosis of NPC was based on inspection of histopathology biopsies conducted by medical doctors in the Department ENT FMUI/RSCM Jakarta. Furthermore, NPC staging was specified based on classification of Union Internationale Contre Cancer (UICC). NPC patient primary in research classified its tumour by Pathologist based on WHO criterion.

\section{Study design}

Design of this research is a descriptive explorative cross sectional study. The sample used in this research is 3 millilitre $(\mathrm{ml})$ peripheral blood from NPC patients and healthy donors. According to Sastroasmoro and Ismae $^{14}$ using formula minimum samples with total amount of samples is 100 samples for NPC patients and healthy donors.

\section{Genomic DNA Isolation $^{15}$}

Genomic DNA was isolated from blood. Peripheral blood (1,5 ml) was mixed with $4.5 \mathrm{ml}$ Red Blood Cells solutions 1X (199 mM EDTA; $100 \mathrm{mM} \mathrm{KHCO}_{3} ; 1.45$ $\mathrm{NH}_{4} \mathrm{Cl}$ ), centrifuged at 1.500 rotations per minute (rpm) for 10 minutes at $27^{\circ} \mathrm{C}$ to get a pellet. Supernatant was discarded and the pellet was lysed in RBC $1 \mathrm{X}$ and centrifuged like before to get a white pellet. 
Then enhanced $1.3 \mathrm{ml}$ cell lyses solutions $(10 \mathrm{mM}$ Tris $\mathrm{HCl} ; 0.25 \mathrm{mM}$ EDTA; 20\% SDS) and the mixture was incubated at $37^{\circ} \mathrm{C}$ for $30-60$ minutes. Added to $1.3 \mathrm{ml}$ precipitated protein $(5 \mathrm{M}$ ammonium acetate) and vortexed till it turned milky. The mixture was centrifuged with $3.000 \mathrm{rpm}$ at $4^{\circ} \mathrm{C}$ for 15 minutes till it formed a brown pellet. Supernatants were transferred to new tubes containing $2.3 \mathrm{ml}$ cool isopropanol and the tubes were inverted several times until precipitated DNA was visible. The DNA was then incubated overnight at $-20^{\circ} \mathrm{C}$. Tubes containing isopropanol-incubated DNA were centrifuged at $3.000 \mathrm{rpm}$ at $4^{\circ} \mathrm{C}$ for 5 minutes. The DNA pellet is cleaned with $1.3 \mathrm{ml}$ sterilized alcohol $70 \%$, centrifuged at $3.000 \mathrm{rpm}$ at $4^{\circ} \mathrm{C}$ for 5 minute. DNA dry-aeration was run for 2 hours at RT. Furthermore, 300 $\mathrm{ml}$ TE (10 mM Tris HCl; $0.25 \mathrm{mM}$ EDTA) was added to dissolve the DNA pellett and incubated at $37^{\circ} \mathrm{C}$ for 2 hour. After that, DNA was transferred to eppendorf tubes of $1.5 \mathrm{ml}$ and stored at $-20^{\circ} \mathrm{C}$.

\section{TCR-ß DNA amplification and PCR-RFLP Technique}

Amplification of TCR- $\beta$ gene was performed by using forward primer 5, TACC TGGAGGCAGAGGAATG3' and reverse primer 5'CCCTCCCAAGCAGGTTATTT3'. Amplification was done at the TCR- $\beta$ DNA that covers polymorphic sites Bgl II in $1.5 \mathrm{~kb}$ upstream direction of the end of 5' $\mathrm{CB}_{2}{ }^{13}$. Every $50 \mu \mathrm{PCR}$ mixture contain $20 \mu \mathrm{l}$ template DNA, 10 pmol primer, $200 \mathrm{mM}$ dNTPs (dTTP, dCTP, dGTP, dATP), 1.25 units Taq DNA polymerase, buffer solution contains $10 \mathrm{mM}$ Tris- $\mathrm{HCl} \mathrm{pH} 9,50 \mathrm{mM}$ $\mathrm{KCl}, 0.1 \%$ Triton X-100, $1.5 \mathrm{mM} \mathrm{MgCl}{ }_{2}$ and ${ }_{\mathrm{dd}} \mathrm{H}_{2} \mathrm{O}$. Amplification consisted of denaturizing, annealing, and extension cycles at the PCR machine. PCR condition that was used for both primers is early denaturizing at $95^{\circ} \mathrm{C}$ for 3 minutes, final extension for 3 minutes, and 35 cycles with denaturizing in $94^{\circ} \mathrm{C}$ for 30 seconds, annealing in $54^{\circ} \mathrm{C}$ for 30 seconds, and extension in $72^{\circ} \mathrm{C}$ for 40 seconds. For negative control, $20 \mu \mathrm{dd}_{\mathrm{dd}} \mathrm{H}_{2} \mathrm{O}$ were added into PCR mixture. Furthermore, amplification DNA (Amplicon) was checked by electrophoresis at $1 \%$ gel agarose. Into every well agarose enhanced mixture that contained of $10 \mu \mathrm{l}$ amplicon and $3 \mu \mathrm{l}$ loading buffers $(0.25 \%$ bromophenol blue, xylene cyanol, $4 \% \mathrm{~b} / \mathrm{v}$ sucrose) and then DNA separated with electrophoresis in 90 Volt for 60 minutes. For marking was used 100 bp DNA ladder. Bands of DNA fragments were visualized by an ultraviolet illuminator and documented by Polaroid camera.

After the positive result of TCR- $\beta$ DNA amplification was proven with the existence of a DNA band of 229 bp, we furthermore conducted RFLP by using restriction enzyme $\mathrm{Bgl}$ II to detect polymorphism of the TCR- $\beta$ gene. The $15 \mu$ TCR- $\beta$ amplicon enhanced to PCR tube, added ${ }_{\text {dd }} \mathrm{H}_{2} \mathrm{O} 3 \mu$, buffer $\mathrm{O} 2 \mu$, and Bgl II $1 \mu$ l. DNA mixture was incubated at $37^{\circ} \mathrm{C}$ for 3 hours. After incubation, DNA mixture was checked by electrophoresis at $2 \%$ agarose. Into every well of the agarose gel was given enhanced mixture that consisted of $20 \mu \mathrm{l}$ DNA and $3 \mu \mathrm{l}$ loading buffer and then bands were separated electrophoretically like before. Results of PCR-RFLP as indicated by electrophoresis were DNA fragments that were visualized with an ultraviolet illuminator could be expressed positive if 1,2 , or 3 bands of TCR- $\beta$ DNA were found at $229 \mathrm{bp}, 142 \mathrm{bp}$, and $87 \mathrm{bp}$. Bands of DNA were documented with a Polaroid camera to analyse RFLP.

\section{Statistical analyses}

This research used nonparametric statistical analysis; to evaluate distribution and relations between two populations of genotype and allele of TCR- $\beta$ gene Chisquare test was used. ${ }^{16}$

\section{RESULTS}

\section{DNA amplification to detect polymorphic sites of TCR- $\beta$ gene}

Polymorphisms of TCR $\beta$ gene is shown by variation at span of TCR- $\beta$ gene that cover polymorphic site $\mathrm{Bgl}$ II and located on $1.5 \mathrm{~kb}$ upstream direction the end of 5' $\mathrm{C} \beta_{2}$. Amplification area is referred as span of $\mathrm{C} \beta_{1}{ }^{-}$ $\mathrm{C} \beta_{2}$ conducted with PCR, using a primer designed to produce a TCR- $\beta$ PCR product of $229 \mathrm{bp}$. Therefore, successful amplification of TCR- $\beta$ DNA should result in a PCR product of $229 \mathrm{bp}$ (Figure 1.) This condition indicates that the primer has been precisely designed and is matching the expectations.

\section{Analysis of the polymorphisms of TCR- $\beta$ gene with RFLP method}

Polymorphisms of TCR- $\beta$ gene at span of $\mathrm{C} \beta_{1}-\mathrm{C} \beta_{2}$ was determined by undertaking RFLP at $2 \%$ gel agarose. RFLP result from PCR-RFLP TCR- $\beta$ DNA product are indicated through existence of cutting of DNA fragment by restriction enzyme Bgl II that producing 3 size of DNA bands like three genotype, where homozygote AA genotype is represented by single band DNA or wild type $(229 \mathrm{pb})$, homozygote BB genotype is represented by double bands DNA (142 and $87 \mathrm{bp}$ ), and heterozygote $\mathrm{AB}$ genotype is represented by three bands DNA (229 bp, 142 bp, and $87 \mathrm{bp}$ ) (Figure 2). At genotype homozygote AA restriction enzyme Bgl II could not recognize sequences of the restriction site that change from 5'-gatct-3' become 5'-aatct 3', so that band of DNA that formed have single band (229 bp). 
At genotype homozygote $\mathrm{BB}$ restriction enzyme $\mathrm{Bgl}$ II could recognize sequence of restriction site at 5'gatct-3', so that producing band of DNA that formed have double band (142 bp and $87 \mathrm{bp}$ ). Furthermore, the genotype heterozygote $\mathrm{AB}$ is combination by 2 patterns genotype homozygote $\mathrm{AA}$ and $\mathrm{BB}$, so that will producing three DNA bands (229 bp, 142 bp, 87 bp).

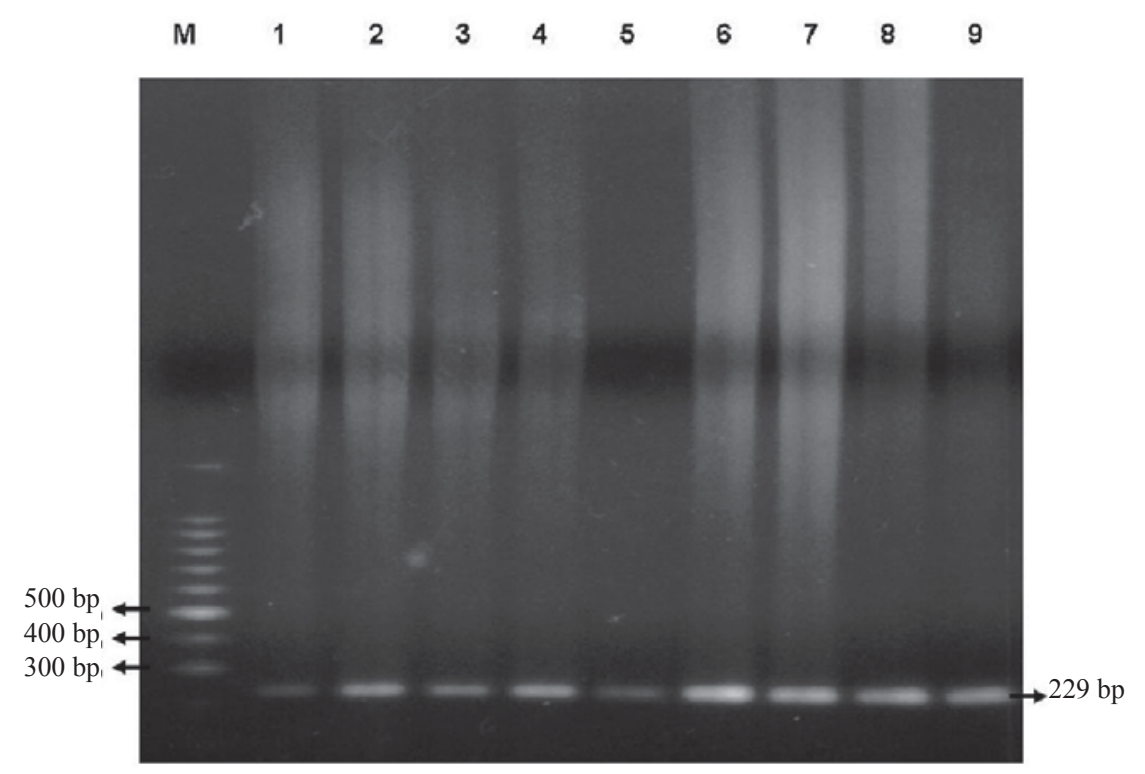

Figure 1. PCR product of 229 bp of TCR- $\beta$ gene after being run on 1\% agarose gel for 60 minutes

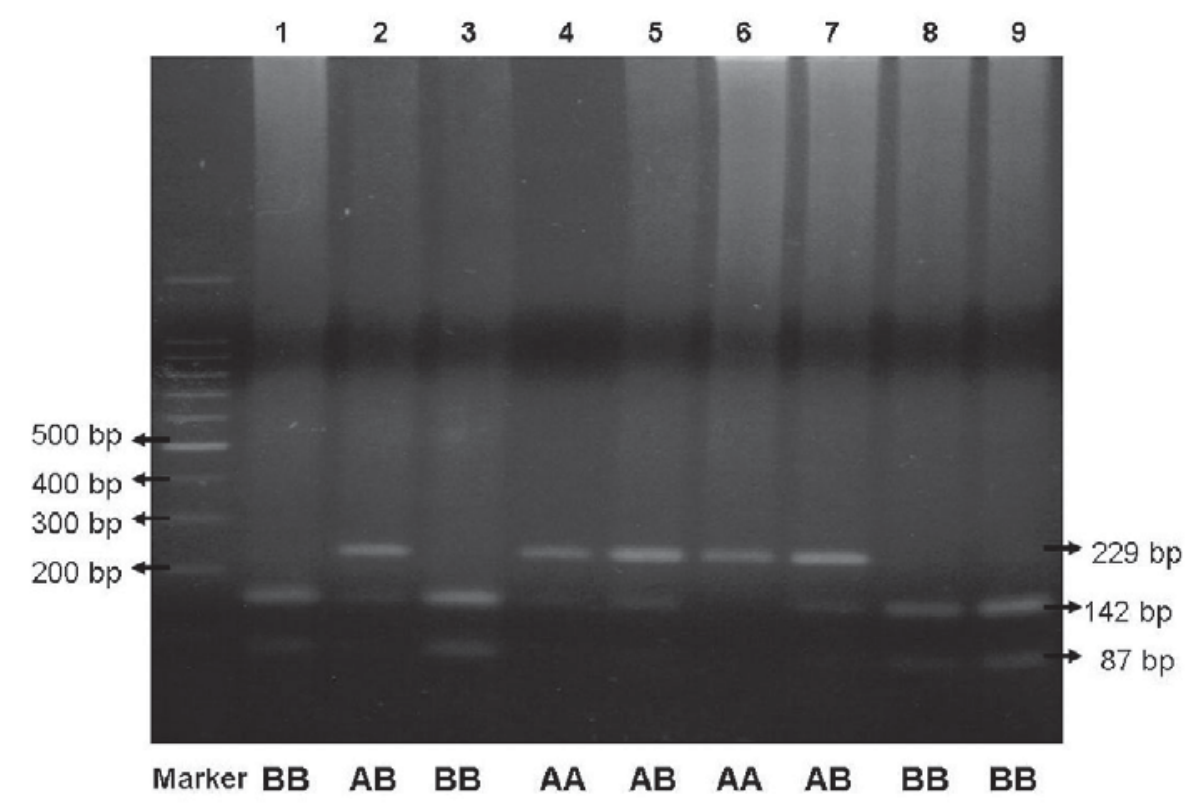

Figure 2. Electrophoresis PCR-RFLP DNA TCR- $\beta$ product in $2 \%$ gel agarose for 60 minutes, visualized with an UV illuminator and documented with a Polaroid camera.

\section{Distribution of TCR- $\beta$ allele on NPC patients and control}

At the Table 1 and Figure 3 we can see the genotype distribution and allele frequency of TCR- $\beta$ gene on NPC group and control group. Tables 1 indicate that genotype distribution of TCR- $\beta$ in NPC population and control shows spreading pattern that is not flatten. At NPC group, BB genotype has highest proportion (49.01\%), AB genotype with lower proportion $(38.23 \%)$, and AA genotype with lowest proportion (12.74\%). At control group, BB genotype have highest proportion (55.55\%), AB genotype with lower proportion $(38,46 \%)$, and AA genotype with lowest proportion $(5.98 \%)$. 
Table 1. Comparison distribution genotype and allele frequency between NPC patients group and control group

\begin{tabular}{lcccccc}
\hline \multirow{2}{*}{ Group } & \multirow{2}{*}{ Total } & \multirow{2}{*}{ AA } & \multirow{2}{*}{ AB } & \multirow{2}{*}{ BB } & \multicolumn{2}{c}{ Allele frequency } \\
\cline { 6 - 7 } & & & & & $\mathrm{A}(\%)$ & $\mathrm{B}(\%)$ \\
\hline NPC & 102 & 13 & 39 & 50 & 31.86 & 68.14 \\
Control & 117 & 7 & 45 & 65 & 25.21 & 74.79 \\
\hline
\end{tabular}

Here in after for allele frequency, at NPC group, B allele has high frequency $(68.14 \%)$, whereas A allele has low frequency (31.86\%). At Non-NPC group, B allele has high frequency $(74.79 \%)$, whereas A allele has low frequency $(25.21 \%)$. Through chi-square test, the allele frequency of TCR- $\beta$ in NPC group did not significantly differ from control group $(\mathrm{p}>0.05)$. Nevertheless, distribution of genotype AA (A allele) is tending to increase on the NPC group.

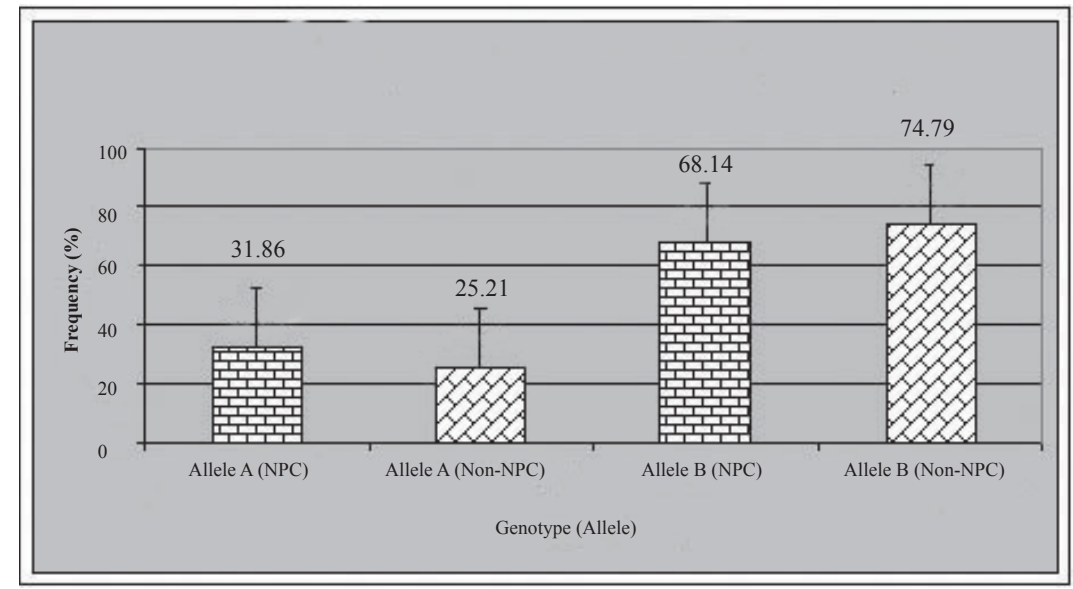

Figure 3. Difference in allele frequency of TCR- $\beta$ gene in patient NPC group and control group ( $p>0.05)$

\section{Distribution of TCR- $\beta$ allele in China ethnic group and indigenous in Indonesia}

Table 2 and Figure 4 show the distribution of genotype and allele frequency TCR- $\beta$ gene at Chinese ethnical group and Indonesian genuine population (Indigenous) group in Indonesia. Distribution of genotype TCR- $\beta$ at indigenous and Chinese in Indonesian population shows spreading pattern that does not flatten. In the indigenous group, $\mathrm{BB}$ genotype has highest proportion (52.24\%), followed by $\mathrm{AB}$ genotype with lower proportion (37.64\%), and AA genotype with the lowest proportion (10.11\%). In the Chinese group, BB genotype has highest proportion $(53.65 \%)$, followed by $\mathrm{AB}$ genotype with lower proportion (41.46\%), and AA genotype with lowest proportion (4.87\%). Furthermore, for the allele frequency, at indigenous group, B allele has high frequency $(71.07 \%)$, whereas A allele has low frequency $(28.93 \%)$. At Chinese group, $\mathrm{B}$ allele has high frequency $(74.39 \%)$, whereas A allele has low frequency $(25.61 \%)$. As a whole in population indicate that B allele has high frequency (71.69\%), whereas A allele has low frequency $(28.31 \%)$. By chisquare test, allele frequency TCR- $\beta$ in Chinese group was not significantly different from indigenous group ( $p>0.05)$. This condition indicated that allele frequency of TCR- $\beta$ gene at ethnical Chinese in Indonesia did not differ from the indigenous population in Indonesia $(\mathrm{p}>0.05)$.
Table 2. Comparison of genotype distribution and TCR- $\beta$ allele at Chinese ethnic group and Indigenous group

\begin{tabular}{ccccccc}
\hline \multirow{2}{*}{ Group } & \multirow{2}{*}{ Amount } & AA & AB & BB & \multicolumn{2}{c}{ Allele Frequency } \\
\cline { 6 - 7 } & & & & & A (\%) & B (\%) \\
\hline Indigenous & 178 & 18 & 67 & 93 & 28.93 & 71.07 \\
Chinese & 41 & 2 & 17 & 22 & 25.61 & 74.39 \\
\hline
\end{tabular}

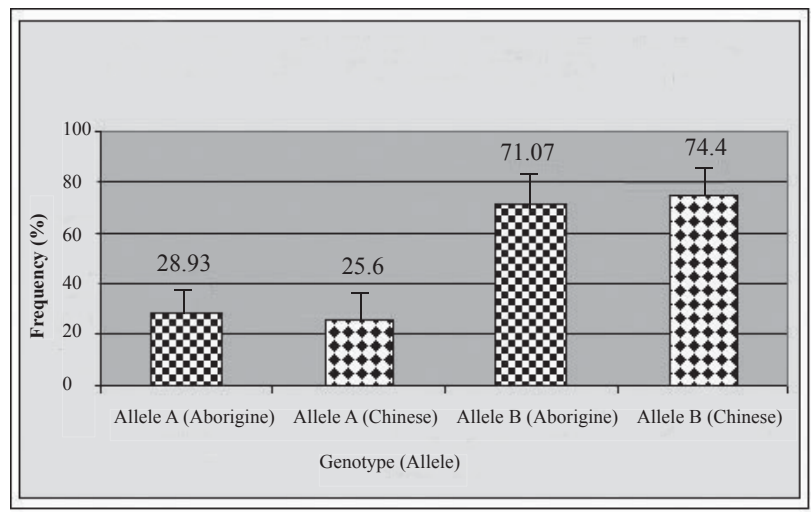

Figure 4. Difference in allele frequency of TCR- $\beta$ gene in Chinese ethnic group and indigenous group in Indonesia $(p>0.5)$.

\section{DISCUSSION}

Polymorphism of the TCR- $\beta$ gene is shown by variation at span of TCR- $\beta$ DNA that covers polymorphic restriction sites of Bgl II and located at 1.5 kilo base pairs, 
upstream direction to the end of 5' $\mathrm{C} \beta_{2}$. Amplification area of span $C \beta_{1}-C \beta_{2}$ are conducted with PCR method. Analysis polymorphism of TCR- $\beta$ gene determine by undertaking PCR-RFLP. From RFLP analysis result that 3 genotypes TCR- $\beta$ gene, where AA genotype are represented by single band DNA or wild type (229 bp), $\mathrm{BB}$ genotype represented double band DNA (142 bp and $87 \mathrm{bp}$ ), and $\mathrm{AB}$ genotype represented three band DNA (229 bp, 142 bp, and 87 bp).

At AA homozygote genotype restriction enzyme Bgl II did not recognize restriction sites sequence that changed from 5'-gatct-3' to 5'-aatct 3', so that the DNA showed a single band (229 bp). At BB homozygote genotype restriction enzyme Bgl II recognized the restriction sites at 5'-gatct-3', so that produce two bands DNA (142 bp and $87 \mathrm{bp}$ ). Hereinafter, $\mathrm{AB}$ heterozygote genotype is combination from 2 patterns AA homozygote genotype and $\mathrm{BB}$ homozygote genotype, so that will produce three bands DNA (229 bp, 142 bp, $87 \mathrm{bp}$ ). In consequence, at PCR-RFLP method changing of endonuclease restriction sites will produce different fragment length DNA. ${ }^{17}$

Table 1 and Figure 3 indicate that distribution of genotype TCR- $\beta$ gene in NPC population and control shown that spreading pattern. By chi-square test, allele frequency of TCR- $\beta$ gene between NPC group was not significantly different with control group $(\mathrm{p}>0.05)$. But, distribution of A allele frequency TCR- $\beta$ gene was tending to increase on NPC group. In this case, it can be anticipated that allotype TCR- $\beta$ gene has influenced with susceptibilities of the individual to NPC, although the reality has been seen yet, where A allele frequency tend to increase at NPC patient and maybe predisposed at NPC pathogeneses. Involvement of A allele as predisposing factor of NPC will possibly be seen it reality if amount samples is improved two till three or conducted samples selection based staging of disease in tightens. Recognition EBV antigen by $\mathrm{T}$ cell through TCR also depend on antigen presentation by molecule HLA until HLA genotype class I and II on NPC patient also need to be considered, because HLA genotype modus certain to present EBV to $\mathrm{T}$ cell determine accuration and strong its cytotoxic response host to cell that infected by EBV. ${ }^{18}$

Table 2 and Figure 4 indicate that distribution of genotype TCR- $ß$ gene at indigenous and Chinese groups in indonesia shows spreading pattern that not flatten. By chi-square test, allele frequency of TCR- $\beta$ gene between indigenous group was not significantly different with Chinese group $(p>0.05)$. This condition indicates that frequency of allele TCR- $\beta$ gene in Chinese ethnic did not differ with indigenous groups in Indonesia. This is indicates that Indonesian people have the same chance with Chinese ethnic in Indonesia to get NPC. This data indicates that maybe gene transfer and transmission have occurred between Chinese ethnic and indigenous from generation to generation.

Several other researches showed that, Chinese ethnic has a high incident of NPC compared to other ethnics, especially in South-East Asia. It is interesting to note the occurrence of NPC in Chinese migrant who has lived in Chinatown San Francisco United States for several generations. There is a significant difference in NPC occurrence from Chinese immigrant compared to other populations such as Caucasians, Negroid, and Hispanics, where Chinese group shows a higher number of NPC cases. ${ }^{19}$ On the contrary, NPC cases in Chinese migrants that live in Chinatown showed a lower number compare to their brothers who live in China. Thus, it is possible that migrant groups still carry genes that are susceptible for NPC, but as a consequence of life style changes and eating habit during living in Chinatown, the trigger factors were suppressed so that the NPC does not develop. ${ }^{19}$

Other epidemiologic evidence occurs in the number NPC in Singapore, where the biggest percentage of NPC is Chinese clan society (18.5 per 100.000 residents), followed up by Malay clan (6.5 per 100.000) and the last is Hindustani clan $\left(0.5\right.$ per 100.000) ${ }^{20}$ Furthermore, in Malaysia occurrence of NPC also many found in the Mongoloid race clan. ${ }^{21}$ That number is significantly higher compared to that in European countries or North America with prevalence 1 per 100.000 per year. ${ }^{22}$ According to research result by Devi et al. in SarawakMalaysia, cases of NPC also have high prevalence, which is 13.5 per 100.000 people. ${ }^{23}$ Even though Korean, Japanese and north Chinese were included in Mongoloid race, not many were found to get NPC. Incidence of NPC in Asian countries is much higher compared to that in Europe or America. In UK, cases of NPC by age $0-14$ year is 0.25 per 1.000 .000 people, whereas by age $10-14$ year is 0.8 per 1.000 .000 people. Age estimating from England and Wales Cancer data indicates that $80 \%$ NPC patient at age 15-19 year, with number of occurrences $1-2$ per 1.000 .000 peoples. ${ }^{24}$

Analysis RFLP in germ-line gene TCR from 41 NPC patients and 54 normal patients at genomic DNA that transformed with EBV become B-lymphoblastoid cell line (BLCL) cutting with restriction enzyme BamHI, EcoRI, HindIII, and TaqI. In the combination of BamHI/ $\mathrm{Vb11}$, NPC patients have lower frequency in fragment size of 25/25-kb and higher frequency at fragment 20$\mathrm{kb}$ compared to control. Combination of TaqI/Vb8, fragment 4.3/3.2-kb has lower frequency at totalize NPC patient, especially in patients with HLA B46. This Result indicates that restriction TCR is anticipated to 
have an important role in response to EBV and NPC pathogenesis. ${ }^{11}$ In a research performed by Hirankarn et al. ${ }^{25}$ the association between HLA-E and genetic susceptibility to nasopharyngeal carcinogenesis was investigated by comparing the frequencies of HLA-E alleles in 100 Thai NPC patients and 100 healthy controls. HLA-E typing was performed by means of PCR-sequence-specific oligonucleotide probe method. The frequency of the HLA-E* 0103 allele and HLA-E 0103, 0103 genotype, but not others, was increased in NPC patients, compared to controls. This observation suggests a possible role for HLA-E in NPC development, possibly via natural killer cell or cytotoxic lymphocyte function. ${ }^{25}$

In conclusion, the distribution of TCR- $\beta$ gene allele between NPC group and control groups showed no difference. The Distribution of TCR- $\beta$ gene between ethnic Chinese and indigenous groups showed no difference. Polymorphisms TCR- $\beta$ gene are not associated with NPC and ethnic groups present in the Indonesian population.

\section{Acknowledgments}

We thank to Irwan Ramli from Department of Radiotherapy and Umar Said Dharmabakti, Armiyanto, and Marlinda Adham from Department of ENT FMUI/ RSCM that has helped in levying samples research. Many thanks also handed to Dwi Ari Pujianto that helps in editing language of this article. This study was supported by HPTP project Directorate of Higher Education (DHE) Department of National Education (DNE).

\section{REFERENCES}

1. Mutirangura A. Molecular mechanisms of nasopharyngeal carcinoma development. Res Adv Res Updat Med. 2000; $1: 18-27$.

2. Mutirangura A, Tanunyutthawongese C, Pornthanakasem W, Kerekhanjanarong V, Sriuranpong V, Yenrudi S. et al. Genomic alteration in nasopharyngeal carcinoma: loss of heterozygosity and Epstein-Barr virus infection. Brit J Cancer. 1997; 76:770-6.

3. Roezin A, Adham M. Karsinoma nasofaring. Dalam: Soepardi EA, Iskandar N, Bashiruddin J, Restuti RD, editor. Buku Ajar Ilmu Kesehatan:Telinga Hidung Tenggorok Kepala dan Leher. Edisi ke 6. Jakarta: Balai Penerbit FKUI; 2007. p. 182-7.

4. Parkin DM, Freddy B, Ferlay J, Pisani P. CA: A Cancer Journal for Clinicians. available from http//:www.caonline. amcancersoc.org./cgi/contet/full/55/2/74. Diakses pada 24 9-2005.

5. Dutt MSN, Watkinson JC. The aetiology of nasopharyngeal carcinoma. Clin Otolaryngol. 2001; 26: 82-92.
6. Roezin A. Food and social background of nasopharyngeal cancer patient in Jakarta. ASEAN Otolaryngol Head \& Neck Surg J. 1997; $1:$ 21-7.

7. Yu MC, Yuan JM. Epidemiology of nasopharyngeal carcinoma. Semin Cancer Biol. 2002; 12:421-9.

8. Straten PT, Schrama D, Andersen MH, Becker JC. clonotypes in cancer. J Translat Med. 2004; 2:11. Available from: http:// www.Translation-Medicine.com/content/2/1/11.

9. Abbas AK, Lichtman AH, Pober JS. Cellular and molecular immunology. 4th ed. Philadelphia: WB. Saunders Company; 2000.

10. Chen Y, Chan SH. Polymorphism of T cell receptor genes in nasopharyngeal carcinoma. Int J Cancer. 1994; 56: 830-3.

11. Berliner N, Dubby AD, Morton CC, Leder P, Seidman JG. Detection of a frequent restriction fragment length polymorphism in the human T cell antigen receptor beta chain locus. A diagnostic tool. J Clin Invest. 1985; 76: 1283-5.

12. Knowless DM. Immunotype and antigen receptor gene rearrangement analysis in T cell neoplasia. Am J Pathol. 1989; 134:761-5.

13. Soeharso P, Summers KM, Cooksley WGE. Allotype distribution of human $\mathrm{T}$ cell receptor $\mathrm{b}$ and $\mathrm{g}$ chain genes in Caucasians, Asians and Australian Aborigines: Relevance to chronic hepatitis B. Human Genet. 1992; 89: 59-63.

14. Sastroasmoro S, Ismael S. Dasar-dasar penelitian klinis. Edisi ke-2. Jakarta: CV Sagung Seto; 2002.

15. Maniatis T, Fritsch EF, Sambrook J. Molecular cloning: A Laboratory manual. 2nd ed. New York: Cold Spring Harbor Laboratory Press; 1989.

16. Medis R. Statistical hand book for non-statistician. London: McGraw-Hill Book Co.: 1975.

17. Nussbaum RL, McInnes RR, Willard HF. Thompson \& Thompson:Genetics in Medicine. 6th ed. Philadelphia:WB Saunders Co.; 2001.

18. Munz C. Immune response and evasion in tha host-EBV interaction. In: Robertson ER, editor. Epstein-Barr Virus. England: Caister Academic-Press; 2005. p. 202-18.

19. Parkin DM, Whelan SL, Ferlay J, Raymond L, Young J. Cancer Incidence in Five Continents. Vol. 7. Lyon: IARC Scient. Publ. ; 1997.

20. Armstrong MW, Armstrong MJ, Yu MC, Henderson BE. Salted fish and inhalant as risk factors for nasopharyngeal carcinoma in Malaysian Chinese. Cancer Res. 1983; 43: 2967-70.

21. See HS, Yap YY, Yip WK, Seow HF. Epstein-Barr virus latent membrane protein-1 (LMP-1) 30-bp deletion and Xho I-loss is associated with type III nasopharyngeal carcinoma in Malaysia. World J Surg Oncol. 2008; 6:18. Available from: http://www.wjso.com/content/6/1/18.

22. Brennan B. Carcinoma nasopharyngeal. Orph J Rar Disease. 2006; 1 (23):1-5.

23. Devi, BCR, Pisani P, Tang TS, Parkin DM. High incidence of nasopharyngeal carcinoma in native people of Sarawak, Borneo Island. Cancer Epidemiol Biomarkers Prev. 2004; 13 (3): 482-6.

24. Susworo, R. Kanker nasofaring: epidemiologi dan pengobatan Mutakhir. Cermin Dunia Kedokteran. 2004; 144: 16-9. [Indonesian]

25. Hirankarn N, Kimkong I, Mutirangura A. HLA-E polymorphism in patients with nasopharyngeal carcinoma. Tissue Antigens. 2004; 64: 588-92. 